Michael Pye

Strategies in the Study of Religions 


\title{
Religion and Reason
}

Founded by Jacques Waardenburg

\author{
Edited by \\ Gustavo Benavides and Michael Stausberg
}

Volume 51

De Gruyter 
Michael Pye

Strategies in the Study of Religions

Volume One: Exploring Methods and Positions

De Gruyter 
ISBN 978-1-61451-249-3

e-ISBN 978-1-61451-189-2

ISSN 0080-0848

\section{Library of Congress Cataloging-in-Publication Data}

A CIP catalog record for this book has been applied for at the Library of Congress.

\section{Bibliographic information published by the Deutsche Nationalbibliothek}

The Deutsche Nationalbibliothek lists this publication in the Deutsche Nationalbibliografie; detailed bibliographic data are available in the Internet at http://dnb.dnb.de.

(C) 2013 Walter de Gruyter GmbH, Berlin/Boston

Printing: Hubert \& Co. GmbH \& Co. KG, Göttingen

$\infty$ Printed on acid-free paper

Printed in Germany

www.degruyter.com 


\section{Dedication}

This work is dedicated to

Christine Pye

who has accompanied my comings and goings for so many years and supported my endeavours with endlessly faithful criticism and good-will 
